\title{
IGF2R wt Allele
}

National Cancer Institute

\section{Source}

National Cancer Institute. IGF2R wt Allele. NCI Thesaurus. Code C51549.

Human IGF2R wild-type allele is located within $6 q 26$ and is approximately $137 \mathrm{~kb}$ in length.

This allele, which encodes cation-independent mannose-6-phosphate receptor protein, plays a role in protein sorting and receptor signal transduction. 